\title{
On the Curriculum Design of Foreign Language and Literature Majors in Application-oriented Institutes
}

\author{
Jianrong Li \\ Heihe University \\ Heihe, Heilongjiang, China
}

\begin{abstract}
The foreign language and literature majors in application-oriented institutes aim to cultivate foreign language teachers, teaching administrators and other educators with noble teaching ethics and solid foreign language knowledge, who are also rich in practical abilities and humanistic qualities and devoted to education. Scientific and reasonable curriculum design of foreign language majors in application-oriented institutes is the basic means and esstential condition to realize the cultivating purpose.
\end{abstract}

Keywords-application-oriented institutes; foreign language and literature majors; the curriculum design

\section{INTRODUCTION}

Application-oriented institutes aim to cultivate application-oriented undergraduate talents in the front line of production, construction, administration and service to meet the needs of the regional economy and social development. The cultivation of application-oriented talents focuses on how to transform knowledge into abilities. The abilities of students who study in foreign language and literature majors are based on all-round improvement of their comprehensive qualities. The personnel training model implementation of foreign language and literature majors in application-oriented institutes is liable to offer broader major choices and promote students' individual development, which benefits students' subjectivity and creativity, especially society's choices of foreign language talents.

The arrangement and design of curriculum serves the talent training goal[1]. According to the requirements of enrolment in classification, the talent training goal of foreign language and literature majors in application-oriented institutes is to cultivate applied foreign language talents with physical and mental health, morality, solid foreign language knowledge, broadening view and abilities of thinking, creativity and practice to meet the need of local economical development. In order to achieve this goal, it is essential to strengthen the education idea of blending scientific education and humanistic education. Moreover, it is necessary to construct the educational training pattern of blending general education and major education. However, the medium of realizing such educational idea and training pattern depends

This article is the research result of the Twelfth Five-Year Plan Key Project of Heilongjiang Educational Science in 2015, The Research and Practice of the Personnel Training Pattern of the Foreign Language and Literature Majors in Application-oriented Institutes. The project number is GJB1215047. on scientific and reasonable design of specialized core courses and general education courses.

\section{THE BASIC PRINCIPLES OF THE CURRICULM DESIGN OF FOREIGN LANGUAGE AND LITERATURE MAJORS}

Designing curriculum is just to realize the goal of education. Therefore, the design of curriculum should be united with the goal. The curriculum design of the foreign language majors observes the following three principles.

\section{A. Orienting Correctly and Broadening Major Fields}

The talent training of foreign language majors should conincide with the development of society and the general goal of the development of application-oriented institutes and talent training. It is important to strengthen the core of majors and highlight the feature of majors according to the characteristics of different subjects. Besides, speciality elective courses should be designed flexibly to cultivate diversified talents with major speciality.

The basic education is broadened during the former period and majors are emphasized during the latter period. The students are cultivated in classification during the first academic year, who study on the same platform of common required elementary courses and specialized elementary courses without their own classified majors. An academic year later, the students choose specific majors again according to their own interest, specialty, individual development orientation and social requirements. Constructing the curriculum platform stabilizes the major foundation and broadens the major field. At the same time, students can postpone their choices of majors, which is bound to benefit their scientific and reasonable major choices.

\section{B. Optimizing the Curriculm System and Strengthening the Practice Link}

The design of the practice link should be optimized. The practical teaching system is constructed hierarchically and periodically with the main line of cultivating students' basic skills, specialized abilities and comprehensive abilities. Thus, the contents, medium and ways of practice teaching is enriched and students' comprehensive practical abilities are improved. In addition, teaching in class is combined with extracurricular teaching by means of encouraging students to take part in scientific reasearch, scientific technology activities, innovating and pioneering activities and all kinds of competitions, such as reading, interpretation or oral 
contests, etc. to cultivate students' originality and comprehensive practical abilities. The curriculum design should also give prominence to career planning, pioneering education and career guidance to enhance students' pioneering awareness and career abilities.

\section{Offering Individualized Quality Education for Every Student and Improving Personality Development}

The curriculum design is bound to reflect the combination of unification and diversity. The teaching plan is arranged properly to enlarge students' power of self-study and choices as well as students' time and space of self-study. The types of elective courses should be enlarged to promote students' self-study. For instance, the courses of pschological health education, safety education, college student career planning and college student career guidance can be established in accordance with freshmen's pschological pressure, indifferent consciousness of saftey and confusion about their future employment to meet the cultivating goal of solid foundation and broad choices.

The curriculum design has to refect not only its wideranging feature but also its appropriate feature, which should be broad and appropriate to meet the need of different students' personality development.

\section{THE OVERALL IDEA OF THE CURRICULUM DESIGN}

The schooling length of the foreign language and literature majors students is four years. The education process includes two stages of general education and specialized education. The general education stage is set during the first and the second term, when students' general elementary education is strengthened and comprehensive abilities are developed. During the speialized education stage, students' practical and innovative abilities are developed. The general education courses are composed of general required courses and general elective courses. The general required courses are established during the first term, which should contain about four hundred periods (not including practice teaching periods) and cannot be less than 30 credits. The general elective courses are established during the second to the sixth term, which should not be less than one hundred and twenty periods (not including practice teaching periods) and cannot be less than 7.5 credits. The specialized courses are composed of specialized core theory courses, online courses and practice teaching process. Different institutes can adjust the varieties of specialized core courses and general education courses and the proportion of the periods and credits accordingly.

\section{The GOAL OF THE CURRICULUM DESIGN}

The goal of the foreign language and literature majors curriculum design is to improve students' comprehensive abilities and personality qualities. Students' comprehensive abilities include the abilities of expressing their ideas with native and foreign languages, abilities of communicating with others, abilities of studying foreign languages lifelong, abilities of storing solid and profound foreign language knowledge, abilities of language communicating to adapt to the requirement of society and markets. Students' personality qualities include noble sense of patriotism, noble morality and perfect personality.

The combination of specialized education and general education will achieve the result of teaching students to know how to behave and do everything in society. The specialized education mainly teaches students to know how do everything by means of theoretical and practical teaching. The general education mainly teaches students to know how to conduct themselves by means of in-class teaching, life experience and environmental influence because the general education idea pay great attention to combining knowledge with abilities[2], which aims to cultivate students' perfect personality by their learning systematic knowledge. The approach of knowledge economy era has given a challenge to talent factors, learning styles and the function of institutes. Therefore, the personnel training in application-oriented institutes needs to improve students' level of conducting themselves and doing everything in society in an all-round way by means of optimizing specialized curriculum and choosing general curriculum carefully.

\section{THE MEANS OF THE CURRICULUM DESIGN}

The means of the curriculum design directly influences the effect of the curriculum. In general, the curriculum system of the foreign language and literature majors in application-oriented institutes should be optimized as a whole based on the requirements of personnel training goal and training pattern. On the whole, the curriculum system of the foreign language and literature majors in applicationoriented institutes is composed of the general education curriculum module, the classification foundation curriculum module, the specialized curriculum module, the practice teaching module and the module of quality extension and innovation practice. Thus, the curriculum system of general education + classification foundation + specialized curriculum + practical teaching + quality extension and innovation practice is constructed. The proportion of different curriculum modules should be arranged appropriately and the curriculum contents need to be renewed and condensed. The curriculum contents avoid overlapping, repeating and disconnecting. The latest achievement in scientific techonology and social development should be infused into the curriculum in time.

\section{A. The General Education Curriculum Module}

The general education curriculum includes general required courses and general elective courses.

The general required courses are designed to develop students' political quality, theoretical level, moral character, physical constitution and basic abilities, which include the common foundation courses that must be arranged in institutes according to the rules of National Education Bureau, such as political theory courses, computer foundation courses and college physical education courses, and the general required courses that are arranged by institutes themselves, such as mental health education courses, safety education courses, college student career planning courses and college student career guidance courses etc. 
The general elective courses are designed to enhance students' cultural and personality qualities, which aim to cultivate students' scientific spirit of pursuing truth, advocating innovation, respecting practice and encouraging reason, to develop students' humanistic quality of mental health, noble sentiments and character. The general elective courses can be arranged by institutes so that institutes are able to make best of the comprehensive advantage of their subjects and curriculum resources. The general elective courses mainly involve the natural science category, the human social science category, the art and physical education category, the linguistic skill category and the innovative education category. Different institutes can add interdisciplinary courses in the light of their specific conditions. Students can choose whichever they like or take restricted courses, all of which are suitable for establishing during the second term to the sixth term.

\section{B. The Classification Foundation Curriculum Module}

The classification foundation courses are the basis on which students learn their specialized required and elective courses, which mainly involve specialized foundation knowledge, the basic theories and skills. The foreign language and literature majors build the platform of the specialized foundation courses based on the classification. The specialized introductory courses which last sixteen periods are offered during the second term and sum up one credit in total. The classification foundation curriculum module aims to help students enhance their major concept and establish their major ideal.

The linguistic teaching and the learning rules are the scientific basis on which the curriculum design of the foreign language and literature majors lays. Wen Qiufang said, "Both academic and applied talent training need to start with language education, which must last during the whole process of undergraduate education." [3] The classification foundation course design of the foreign language and literature majors must involve students' future reassigned major, which has to lay a solid linguistic foundation for students and improve their abilities of using languages.

\section{The Specialized Curriculum Module}

The specialized curriculum module includes the specialized required courses and the specialized elective courses.

The specialized required courses of the foreign language and literature majors are the stem courses which aim to cultivate students' foreign language specialized core knowledge, specilized quality and abilities. The courses need to reflect the linguistic feature of majors, which should be fewer in quantity but better in quality. The cultivation of students' linguistic specialized abilities should be focused on to design the specialized required courses. The core courses can be established according to The Undergraduate Major List and Introduction of Ordinary Colleges and Universities issued by Higher Education Bureau in Ministry of Education, such as Phonetics, Listening and Speaking, Morphology, Syntax, Theory and Practice of Translation, History of Literature and Teaching Methods, etc.
The specialized elective courses of the foreign language and literature majors include the specialized elective courses which are compulsory and the specialized elective courses which are optional. The specialized elective courses are offered to broaden and deepen students' foreign language major knowledge, which meet students' individual specialized learning. The quantity of the elective courses are supposed to meet what the students need when they take courses.

\section{The Practice Teaching Module}

Language learning happens in the social environment and must be influenced by certain social factors. [4] Not only the required courses and the elective courses are arranged in the curriculum design but also the practice link should be optimized. The practice link module includes education practice, specialized practice and training, the graduation thesis design and comprehensive training, military training, labour for public good and social practice, etc.

The practice teaching link, such as education practice, specialized practice and training, the graduation thesis design and comprehensive training should comply with correlative provisions and requirements of the teaching administrative departments in our country, which is organized and arranged by each major itself. The graduation thesis design and comprehensive training is arranged during the eighth term, which should be no less than eight weeks, but no more than twelve weeks.

Military training is arranged during the second term and is organized with other colleges together, which lasts two weeks. Labour for public good lasts one week, not taken up the teaching periods. Students' Labour Department takes charge of the activity of labour for public good, which is held together with other colleges during out-of-class time. Social practice includes social survey, production labour, volunteering service, labour for public good and part-work and part-study, etc., which is held together with other colleges. The activities of social practice last no less than four weeks, not taken up the teaching periods.

\section{E. The Module of Quality Extension and Innovation Practice}

The module of quality extension and innovation practice is designed to cultivate students' comprehensive qualities and innovative abilities, including the activities of scientific research, subject competitions, scientific and technical inventions, literature creation and all sorts of innovation and pioneering education, etc. Students are encouraged to take part in scientific research, scientific and technical activities, all sorts of innovation and pioneering education activities and competitions, such as reading contests, interpretation contests or oral contests, etc. to cultivate students' creative abilities and comprehensive practical abilities. All the activities in this module are taken charge of by the League Member Committee and held with other colleges together. 


\section{THE RULES OF THE PERIOdS AND CREDITS OF THE CURRICULUM}

The total in-class periods of the foreign language and literature majors should be restricted within 2,750 periods and the total credits should be restricted within 175 to 185 credits until students' graduation. The credit(period) ratio of the specialized required courses to the specilized elective courses is six to four.

The total credits(periods) of practice teaching should be no less than $20 \%$, in which military training takes up 2 credits, quality extension and innovation practice 5 credits, social practice 2 credits and labour for public good taken up no credits.

\section{CONCLUSION}

It is essential for the personnel training of the foreign language and literature majors in application-oriented institutes to design scientific and reasonable curriculum. Scientific and reasonable curriculum design is also the key way for students to promote their quality and comprehensive abilities of application. Application-oriented institutes should base themselves upon their reality and design the curriculum goal around the personnel trainning goal. The curriculum contents are to design scientifically and properly. The barriers between courses are to be removed and the relationship between the education training goal and teaching is to be explored to establish the high-quality curriculum system. High-quality curriculum system helps promote the social value of talents who major in foreign languages and ensure application-oriented foreign language talents' competitiveness in markets.

The design of the curriculum system and the order of offering courses must correspond to students' cognitive pattern. [5] The specialized core courses must be highlighted when the specialized required courses are designed. And it's better to make use of the platform of Online teaching resources to develop teaching activities. Teachers also need to cultivate students' consciousness and abilities of general education in teaching. When students learn specialized knowledge, they should not only master the specific knowledge within the subjects but also understand the connotation of knowledge and develop the abilities of obtaining knowledge so that the employment market can get enough foreign language talents who can also realize their own self-value.

The curriculum contents should put emphasis on students' qualities on the levels of knowledge, morality and society. The foreign language and literature majors courses in application-oriented institutes are the medium to cultivate students' complete personality so that students will grow into individuals with profound knowledge and abilities to adapt to the society. Besides, the curriculum design should also focus on the close link between the curriculum contents and the social requirements. Meanwhile, inheriting and passing on local culture as well as open internationalization should also be involved in the curriculum design. In addition, some courses with speciality need to be offered according to the major direction to ensure students to have reasonable structures of knowledge and abilities.

In general, the comprehensiveness, entirety and interrelationship between courses should be considered when the courses are designed. It is important to merge the humanistic value, such as awareness of the obligations of a citizen, ethical attainments and critical awareness into the curriculum. In-class courses are combined with out-of-class practice so that students' comprehensive qualities are improved and high-quality foreign language talents are cultivated to adapt to the society. Furthermore, institutes can readjust the specific combination way and contents of the curriculum according to their own features for setting up and different special emphases on the local economy.

\section{REFERENCES}

[1] Chenfen, Xie Anbang. An Exploration to the Application-oriented Talents' Ability Cultivation — Thoughts Based on the Construction of the Curriculum System[J]. Modern University Education, 2011:65.

[2] Li Manli. General Education_ — K Kind of University Education Viewpoints[M].Beijing: Qinghua University Press, 1999:15-18.

[3] Wen Qiufang. The Challenge and Strategy Faced by Practical Multiple Talent Idea of English Language Classification[J]. Foreign Language Teaching and Research, 2014,1:123-124.

[4] Barkhuizen, Gary, Social Influences on Language Learning[M]. Oxford: Blackwell Publishing Ltd., 2004:553.

[5] Dublin, Fraida \& Elite Olshtain. Course Design[M]. Shanghai: Shanghai Foreign Language Education Press, 2002:83-85. 